\title{
KETERJADIAN PENYAKIT TERSEBAB JAMUR PADA HAMA PENGGEREK BUAH KOPI (Pbko) DI PERTANAMAN KOPI AGROFORESTRI
}

\author{
Juwita Suri Maharani, F.X. Susilo, I Gede Swibawa \& Joko Prasetyo \\ Jurusan Agroteknologi, Fakultas Pertanian, Universitas Lampung \\ Jl. Soemantri Brodjonegoro No. 1 Bandar Lampung 35145 \\ E-mail:juwitasuri@ymail.com
}

\begin{abstract}
ABSTRAK
Penelitian ini bertujuan untuk mengetahui keterjadian penyakit tersebab jamur pada hama penggerek buah kopi (Pbko) di pertanaman kopi agroforestri di Sumber Jaya, Lampung Barat. Penelitian ini dilakukan dengan menggunakan metode survei (sigi). Survei atau pengambilan sampel buah kopi dilakukan di areal perkebunan kopi rakyat yang ditanam dengan sistem agroforestri yaitu agroforestri sederhana dan agroforestri kompleks. Hasil penelitian menunjukkan bahwa keterjadian penyakit tersebab jamur Pbko pada sampel buah kopi dari pohon di agroforestri kompleks lebih tinggi $(45,8 \%)$ dibandingkan dengan agroforestri sederhana $(27,2 \%)$. Keterjadian penyakit tersebab jamur Pbko pada buah kopi di tanah lebih tinggi dibandingkan dengan yang masih berada di pohon, baik pada sistem agroforestri kompleks (65,3\% vs 45,8\%) maupun pada agroforestri sederhana $(61,3$ vs $27,2 \%)$.
\end{abstract}

Kata Kunci : penyakit tersebab jamur, penggerek buah kopi, agroforestri.

\section{PENDAHULUAN}

Di Indonesia kopi merupakan salah satu komiditi ekspor yang mempunyai arti yang cukup penting. Selain sebagai komoditi ekspor, kopi juga merupakan komoditi yang dikonsumsi di dalam negeri. Menurut survei yang pernah dilakukan Departemen Pertanian, rata-rata penduduk Indonesia mengkonsumsi kopi sebanyak 0,5 $\mathrm{kg} /$ orang/tahun (Najiyati dan Danarti, 2001). Dengan demikian dengan jumlah penduduk Indonesia \pm 170 juta, maka diperkirakan setiap tahun diperlukan stok kopi sebanyak 85.000 ton kopi untuk keperluan konsumsi dalam negeri.

Lampung merupakan salah satu provinsi pemasok kopi terbesar bagi Indonesia untuk diekspor ke luar negeri. Provinsi Lampung selama ini dikenal sebagai salah satu produsen utama kopi Indonesia dan sekaligus juga merupakan pintu gerbang utama ekspor kopi Indonesia (AEKI, 2011).

Pertanaman kopi di Lampung pada umumnya bersistem monokultur (Afandi, 2004). Pola tanam kopi monokultur ini memiliki beberapa kelemahan antara lain lebih rentan terhadap gangguan OPT, memiliki masukan seresah yang rendah, kanopi terbuka, dan kondisi iklim mikronya yang kering yang tidak cocok bagi aktivitas musuh alami hama tanaman (Staver et al., 2001). Untuk memperbaiki ekosistem tersebut dilakukan penanaman kopi bernaungan atau sistem agroforestri.
Agroforestri adalah sistem ekologi di mana pepohonan ditanam di lahan pertanian (Wulandari, 2011). Agroforestri dapat dikelompokkan menjadi dua sistem, yaitu sistem agroforestri sederhana dan sistem agroforestri kompleks. Sistem agroforestri kopi sederhana adalah sistem tumpang sari tanaman kopi bersama dengan satu atau dua jenis pohon penaung dari famili Fabaceae seperti gamal, dadap, sengon, atau lamtoro. Sedangkan pada sistem agroforestri kopi kompleks adalah tanaman kopi ditanam bersama dengan sedikitnya empat jenis pohon penaung baik dari famili Fabaceae maupun pohon buah-buahan dan kayu-kayuan (Rahayu et al., 2006).

Di pertanaman kopi banyak terdapat gangguangangguan yang sangat merugikan, salah satunya yaitu hama penggerek buah kopi (Pbko). Kumbang dan larva hama ini menyerang buah kopi yang sudah cukup keras dengan membuat liang gerekan dan hidup di dalam bijinya, sehingga menimbulkan kerusakan yang cukup parah (Najiyati dan Danarti, 2001).

Penerapan sistem agroforestri pada tanaman kopi yang dicirikan oleh banyaknya pohon penaung memberi beberapa manfaat. Sistem ini dapat meningkatkan keragaman hayati, mengkonservasi kesuburan tanah, dan meningkatkan kesehatan tanaman. Sistem agroforestri memiliki kemiripan dengan hutan yaitu ekosistemnya yang stabil sehingga mampu menghambat 
perkembangan OPT pada tanaman kopi (Staver et al., 2001).

Di alam Pbko dapat diinfeksi oleh jamur patogen. Jamur-jamur yang dapat menyerang Pbko antara lain Beauveria bassiana, Metarhizium anisopliae, Botrytis stephanoderis dan Spicaria javanica (Sudarmo, 1989). Jamur-jamur pada umumnya dapat tumbuh pada keadaan lingkungan yang lembab. Sistem agroforestri kopi dengan pohon penaung diperkirakan dapat meningkatkan aktivitas jamur patogen sebagai musuh alami hama kopi ini. Informasi mengenai keterjadian penyakit jamur pada hama Pbko pada agroforestri masih terbatas.

Penelitian ini bertujuan untuk mengetahui keterjadian penyakit tersebab jamur pada hama penggerek buah kopi (Pbko) di pertanaman kopi agroforestri di Sumber Jaya, Lampung Barat.

\section{METODE PENELITIAN}

Penelitian ini dilakukan dengan menggunakan metode survei (sigi). Survei atau pengambilan sampel buah kopi dilakukan di areal perkebunan kopi rakyat yang ditanam dengan sistem agroforestri yaitu agroforestri sederhana dan agroforestri kompleks. Penelitian ini dilaksanakan pada bulan Juli 2011 sampai Maret 2012. Pengambilan sampel buah kopi dilakukan pada perkebunan kopi rakyat di Desa Suka Jaya, Kecamatan Sumber Jaya, Kabupaten Lampung Barat. Identifikasi jamur dilakukan di Laboratorium Penyakit Tumbuhan, Fakultas Pertanian, Universitas Lampung.

Survei musuh alami hama penggerek buah kopi (Pbko). Pada areal perkebunan rakyat dipilih sepuluh hamparan kebun kopi bersistem agroforestri dengan luas masing-masing $>1 \mathrm{Ha}$. Sepuluh kebun tersebut dikelompokkan menjadi dua tipe, yaitu kebun dengan sistem agroforestri sederhan (lima kebun) dan kebun dengan sistem agroforestri kompleks multistrata (lima kebun). Pengelompokan kebun menggunakan kriteria yang dipakai Dewi et al. (2006), yaitu kebun kopi agroforestri adalah kebun dengan kopi sebagai tanaman pokok dengan pohon penaung $>5$ jenis dan populasinya $>15 \%$. Pada kebun kopi agroforestri kompleks multistrata terdapat pohon penaung $>5$ jenis dengan umur yang tidak seragam, sedangkan pada agroforestri sederhana terdapat pohon penaung $>5$ jenis dengan umur yang relatif seragam. Survei musuh alami dilakukan di dalam transek dengan ukuran 40 x $4 \mathrm{~m}$ pada masingmasing kelompok kebun kopi.

Buah kopi yang terserang penggerek buah kopi (Pbko) dikumpulkan, baik dari dalam transek maupun dari luar transek, baik yang masih di pohon maupun yang telah jatuh ke tanah. Buah kopi yang terserang dan terindikasi jamur dikumpulkan. Buah-buah yang terserang Pbko dan bertanda jamur dikumpulkan juga dari luar transek (3m dari transek) dan dibawa ke laboratorium untuk diidentifikasi.

\section{Penentuan keterjadian penyakit pada Pbko dan} identifikasi jamur patogen. Buah kopi dikumpulkan secara manual baik dari dalam maupun luar transek. Selanjutnya seluruh buah kopi yang telah dikumpulkan dihitung jumlahnya untuk dibawa ke laboratorium.

Buah-buah kopi yang terserang Pbko (berlubang gerekan) dan bertanda jamur dikumpulkan dan dihitung jumlahnya. Buah kopi bertanda jamur adalah yang pada bekas lubang gerekan Pbko ditumbuhi oleh massa jamur. Penghitungan Keterjadian Penyakit menggunakan rumus sebagai berikut.

$$
\mathrm{KP}=\frac{\mathrm{n}}{\mathrm{N}} \times 100 \%
$$

dengan KP adalah keterjadian penyakit, $\mathrm{n}$ adalah jumlah buah rusak bertanda jamur, dan $\mathrm{N}$ adalah jumlah seluruh buah yang diamati.

Buah yang berlubang gerekan dan bertanda jamur tersebut kemudian dibelah, serangganya diambil dan jamurnya diisolasi. Isolasi jamur dilakukan dengan cara menumbuhkan jamur pada serangga ke media PDA. Media PDA terbuat dari aquades, kentang, gula, dan agar. Jamur-jamur yang tumbuh kemudian dimurnikan kembali sehingga mendapatkan isolat jamur. Isolat jamur tersebut kemudian diidentifikasi dengan bantuan buku Barnett (1960) .

Penentuan masukan seresah. Pengambilan sampel seresah dilakukan di dalam transek pada titik pengambilan contoh berukuran kuadrat $0,5 \mathrm{~m}$ x 0,5 m. Seresah yang diambil adalah daun, ranting, dan cabangcabang mati yang terdapat di permukaan tanah. Seluruh seresah yang ada pada titik sampel dan berada di permukaan dikumpulkan secara manual yang kemudian dibawa ke laboratorium. Sampel seresah yang telah dikumpulkan dioven selama 48 jam pada suhu $80^{\circ} \mathrm{C}$ dan diukur berat keringnya.

Penentuan iklim mikro. Iklim mikro yang diukur dalam penelitian ini adalah suhu dan kelembaban kadar air tanah pada kedalaman 0-20 cm dan suhu udara di bawah tajuk. Pada setiap titik sampel yang sama dengan pengambilan contoh seresah, dilakukan pengukuran suhu dan kelembaban tanah. Pengukuran suhu tanah dilakukan in situ dengan menggunakan termometer air raksa berbentuk batang. Untuk menghindari kerusakan 
termometer, sebelum dimasukkan kedalam tanah dibuat lubang terlebih dahulu dengan kedalaman $20 \mathrm{~cm}$ menggunakan pipa besi runcing berdiameter sedikit lebih besar daripada diameter batang termometer. Pencacatan suhu dilakukan \pm 15 menit setelah termometer dimasukkan ke dalam tanah. Setelah itu, termometer digantungkan pada ranting bawah untuk mengukur suhu udara.

Pada setiap titik sampel, tanah terusik diambil sebanyak $\pm 0,5 \mathrm{~kg}$ dengan menggunakan cetok kebun pada kedalaman 0-20 cm. Tanah kemudian dimasukkan di dalam kantong plastik dan dibawa ke laboratorium. Sebanyak 100 gr contoh tanah dioven pada suhu $105^{\circ} \mathrm{C}$ selama 48 jam atau sampai tidak terjadi pengurangan berat untuk menentukan kadar air tanah menggunakan metode gravimetri, sebagai berikut (Susilo dan Karyanto, 2005).

Kadar Air Tanah Aktual $=\frac{\text { Berat basah }- \text { Berat kering }}{\text { Berat kering }} \times 100 \%$

Penentuan tutupan kanopi. Pada setiap transek seluruh pohon penaung diidentifikasi dan dihitung jumlah masing-masing jenis pohon yang terdapat pada setiap kebun kopi. Setiap pohon yang berada dalam transek diukur jari-jari kanopi pada empat arah posisi kiri, kanan, depan, dan belakang. Posisi pohon dan sebaran kanopi pada lahan dipetakan pada kertas grafik dan dihitung persentase penutupan kanopi dengan asumsi sebaran kanopi pohon berbentuk lingkaran. Persentase tutupan kanopi dihitung dengan rumus sebagai berikut (Aini et al., 2006).

Tutupan Kanopi $=\frac{\text { Jumlah seluruh luas tutupan kanopi }}{\text { Luas plot trans ek }} \times 100 \%$

Analisis data. Dari hasil pengamatan keterjadian penyakit jamur pada Pbko dianalisis secara statistik dengan uji t pada taraf nyata $1 \%$ atau $5 \%$.

\section{HASIL DAN PEMBAHASAN}

Hasil pengamatan pada tutupan kanopi menunjukkan bahwa pada kebun kopi dengan sistem agroforestri kompleks terdapat lebih banyak jenis pohon penaung daripada tipe agroforestri sederhana (Tabel 1). Berdasarkan hasil pengamatan tutupan kanopi pohon penaung pada kebun kopi dengan sistem agroforestri kompleks yang mencapai 78,8\% sangat nyata lebih tinggi dibandingkan dengan tutupan kanopi pohon penaung pada kebun kopi agroforestri sederhana yang hanya sekitar 43,6\%. Tutupan kanopi pohon penaung mempengaruhi intensitas sinar matahari yang sampai ke lantai kebun pertanaman kopi. Jumlah seresah tidak berbeda nyata pada kebun kopi dengan sistem agroferestri kompleks yaitu sebesar 49,9gr/0,025 m²

Tabel 1. Jenis-jenis pohon penaung yang terdapat pada kebun kopi dengan sistem agroforestri kompleks dan sederhana di Sumber Jaya

\begin{tabular}{|c|c|c|c|}
\hline \multirow{2}{*}{ No } & \multirow{2}{*}{ Jenis Pohon } & \multicolumn{2}{|c|}{ Sistem agroforestri } \\
\hline & & Kompleks & Sederhana \\
\hline 1. & Cengkeh (Eugenia aromatica) & $\mathrm{v}$ & \\
\hline 2. & Dadap (Erythrina indica) & $\mathrm{v}$ & $\mathrm{v}$ \\
\hline 3. & Durian (Durio zibethinus) & $\mathrm{v}$ & $\mathrm{v}$ \\
\hline 4. & Mangga (Mangifera indica) & $\mathrm{v}$ & \\
\hline 5. & Pinang (Areca catetchu) & $\mathrm{v}$ & \\
\hline 6. & Melinjo (Gnetum gnemon) & $\mathrm{v}$ & \\
\hline 7. & Jengkol (Pithecollobium jiringa) & $\mathrm{v}$ & \\
\hline 8. & Petai (Parkia speciosa) & $\mathrm{v}$ & \\
\hline 9. & Afrika (Maesopsis emini) & $\mathrm{v}$ & $\mathrm{v}$ \\
\hline 10. & Nangka (Artocarpus heterophyllus) & $\mathrm{v}$ & $\mathrm{v}$ \\
\hline 11. & Kelapa (Cocos nucifera) & $\mathrm{v}$ & \\
\hline 12. & Cempedak (Artocarpus champedon) & $\mathrm{v}$ & \\
\hline 13 & Karet (Hevea brasiliensis) & $\mathrm{v}$ & \\
\hline 14. & Pisang (Musa sp.) & $\mathrm{v}$ & $\mathrm{v}$ \\
\hline 15 & Gamal (Gliricidia sepium) & $\mathrm{v}$ & $\mathrm{v}$ \\
\hline 16. & Mahoni (Swietenia macrophilla) & & $\mathrm{v}$ \\
\hline
\end{tabular}


dibandingkan dengan agroforestri sederhana yang sebesar 55,9 gr/0,025 $\mathrm{m}^{2}$ (Tabel 2).

Kadar air tanah pada agroforestri kompleks, yaitu sebesar 49,08\% tidak berbeda nyata dibandingkan dengan agroforestri sederhana yaitu 48,57\%. Sementara itu suhu dalam tanah pada agroforestri kompleks ratarata sebesar $22,4{ }^{\circ} \mathrm{C}$ tidak berbeda nyata dibandingkan dengan agroforestri sederhana yang sebesar $22,8{ }^{\circ} \mathrm{C}$. Begitu juga dengan pengamatan suhu udara pada agroforestri kompleks rata-rata sebesar $25,8{ }^{\circ} \mathrm{C}$, tidak berbeda nyata dibandingkan dengan agroforestri sederhana yang sebesar $25^{\circ} \mathrm{C}$ (Tabel 3).

Keterjadian penyakit bertanda jamur pada Pbko pada agroforestri kompleks secara nyata lebih tinggi $(45,8 \%)$ dibandingkan dengan pada agroforestri sederhana $(27,2 \%)$. Persentase keterjadian penyakit bertanda jamur pada buah di tanah lebih tinggi dibandingkan dengan keterjadian penyakit pada buah kopi yang masih berada di pohon, baik pada sistem agroforestri kompleks $(65,3 \%$ vs $45,8 \%)$ maupun pada agroforestri sederhana (61,3 vs $27,2 \%$ ) (Tabel 4).
Hasil persentase keterjadian penyakit akibat buah rusak bertanda jamur pada sampel buah kopi dari Sumber Jaya yaitu pada buah dari pohon menunjukkan bahwa keterjadian penyakit hama Pbko pada agroforestri kompleks $(45,8 \%)$ secara nyata lebih tinggi dibandingkan dengan agroforestri sederhana $(27,2 \%)$. Hal ini mungkin berkaitan dengan jumlah pohon penaung pada agroforestri kompleks yang lebih banyak dibandingkan dengan agroforestri sederhana (Tabel 1). Fahmi (2003) menyebutkan bahwa tingkat naungan yang semakin tinggi akan menurunkan intensitas cahaya.

Sementara itu intensitas cahaya yang tinggi dapat menghambat pertumbuhan jamur (Yusef dan Allan, 1967). Akibatnya keterjadian penyakit jamur rendah pada Pbko, yang dicirikan dengan rendahnya persentase buah kopi rusak bertanda jamur, pada sistem agroforestri sederhana. Hal itu nampak pada buah-buah kopi yang masih berada pada pohon-pohon kopi. Selain itu intensitas cahaya berkaitan dengan kelembaban udara; semakin sedikit intensitas cahaya yang masuk ke suatu habitat maka kelembaban udara di haabitat itu akan

Tabel 2. Tutupan kanopi dan jumlah seresah pada kebun kopi dengan sistem agroforestri kompleks dan sederhana di Sumber Jaya

\begin{tabular}{lccc}
\hline Peubah & Agroforestri kompleks & Agroforestri sederhana & t hitung \\
\hline Tutupan Kanopi $(\%)$ & 78,8 & 43,6 & $3,5^{* *}$ \\
Jumlah Seresah $\left(\mathrm{gr} / 0,025 \mathrm{~m}^{2}\right)$ & 49,9 & 55,9 & $-1,1^{\text {th }}$ \\
\hline
\end{tabular}

Keterangan $:{ }^{* *}=$ dua nilai tengah pada baris yang sama sangat berbeda nyata $\left(\alpha_{0,01}\right) ;{ }^{\text {tn }}=$ tidak berbeda nyata menurut uji $\left(\alpha_{0,05}\right)$.

Tabel 3. Kadar air tanah, suhu tanah dan suhu udara pada kebun kopi dengan sistem agroforestri kompleks dan sederhana di Sumber Jaya

\begin{tabular}{lccc}
\hline \multicolumn{1}{c}{ Peubah } & Agroforestri kompleks & Agroforestri sederhana & t hitung \\
\hline Kadar air tanah $(\%)$ & 49,1 & 48,6 & $0,2^{\text {tn }}$ \\
Suhu dalam tanah $\left({ }^{\circ} \mathrm{C}\right)$ & 22,4 & 22,8 & $-0,9^{\text {tn }}$ \\
Suhu udara $\left({ }^{\circ} \mathrm{C}\right)$ & 25,8 & 25 & $0,5^{\text {tn }}$ \\
\hline
\end{tabular}

Keterangan : ${ }^{\text {tn }}=$ nilai tengah pada baris yang sama tidak berbeda nyata $\left(\alpha_{0,05}\right)$ menurut uji t.

Tabel 4. Keterjadian penyakit Pbko (buah kopi rusak) bertanda jamur (\%)

\begin{tabular}{lccc}
\hline Peubah & Agroforestri kompleks & Agroforestri sederhana & t hitung \\
\hline Buah Pohon & 45,8 & 27,2 & $3,5^{* *}$ \\
Buah Tanah & 65,3 & 61,3 & $0,5^{\text {tn }}$ \\
\hline t hitung & $2,7^{*}$ & $6,5^{* *}$ &
\end{tabular}

Keterangan $: *$ dua nilai tengah pada baris atau lajur yang sama berbeda nyata; $* *=$ dua nilai tengah pada baris atau lajur yang sama sangat berbeda nyata $\left(\alpha_{0,01}\right) ;{ }^{\text {tn }}=$ tidak berbeda nyata menurut uji $\mathrm{t}\left(\alpha_{0,05}\right)$. Sampel diambil dari Sumber Jaya. 
semakin tinggi (Mariani dan Junaedi, 2009). Hal ini berkaitan dengan pertumbuhan jamur patogen yang menghendaki keadaan lingkungan yang lembab. Soetopo dan Indrayani (2007) menyatakan bahwa umumnya cendawan entomopatogen membutuhkan lingkungan yang lembab untuk dapat menginfeksi serangga, oleh karena itu epizootiknya di alam biasanya terbentuk pada saat kondisi lingkungan lembab.

Pada buah-buah kopi yang sudah jatuh di tanah persentase keterjadian penyakit tersebut tidak berbeda nyata antara sistem agroforestri kompleks dan sistem agroforestri sederhana (Tabel 4). Hal ini mungkin berkaitan dengan jumlah seresah yang juga tidak berbeda nyata pada agroforestri kompleks dan agroforestri sederhana (Tabel 2). Seresah yang ada pada permukaan tanah mengurangi intensitas cahaya dan menutupi buahbuah kopi yang ada di tanah, oleh karena itu persentase keterjadian penyakit tidak berbeda nyata pada agroforestri kompleks dan sederhana.

Keterjadian penyakit pada buah yang ada di tanah lebih tinggi dibandingkan dengan keterjadian penyakit pada buah yang masih berada di pohon, baik pada sistem agroforestri kompleks maupun pada agroforestri sederhana (Tabel 4). Hal ini mungkin berkaitan dengan sedikitnya cahaya yang mengenai buah-buah yang berada di tanah dibandingkan dengan yang mengenai buah-buah di pohon. Seresah menutupi buah-buah kopi di tanah sehingga sangat sedikit cahaya yang mengenai buah-buah kopi tersebut. Sementara itu buah-buah kopi di pohon menerima cahaya yang relatif lebih banyak walaupun mendapat naungan dari tajuk pohon-pohon penaung. Naungan pohon pada sistem agroforestri kompleks lebih efektif mengurangi intensitas cahaya daripada naungan pada sistem agroforestri sederhana. Tetapi pengurangan intensitas cahaya oleh seresah lebih efektif daripada oleh naungan pada kedua sistem agroforestri tersebut.

Habitat jamur patogen mungkin juga mempengaruhi keterjadian penyakit jamur. Menurut Arifin et al. (2010) jamur patogen, misalnya B.bassiana, terdapat di dalam tanah sebagai saprofit. Jamur-jamur entomopatogen lainnya juga dapat bertahan dalam tanah dalam bentuk spora rehat selama beberapa tahun dan dalam bentuk miselia atau konidia untuk beberapa bulan (Inglish et al. 1997 dalam Hasyim 2006).

Keterjadian penyakit pada hama Pbko di agroforestri kompleks lebih tinggi dibandingkan dengan keterjadian penyakit di agroforestri sederhana. Sistem agroforestri kompleks memiliki iklim mikro yang mendukung untuk petumbuhan jamur patogen dan nampaknya dapat mengkonservasi jamur patogen sebagai musuh alami. Dengan demikian penerapan sistem agroforestri pada pertanaman kopi diharapkan dapat menjadi alternatif teknologi untuk mengurangi kerusakan yang ditimbulkan oleh tersebut.

\section{KESIMPULAN DAN SARAN}

Keterjadian penyakit tersebab jamur pada hama penggerek buah kopi pada buah-buah kopi yang masih berada di pohon pada agroforestri kompleks secara nyata lebih tinggi (sebesar 45,8 \%) dibandingkan dengan keterjadian penyakit pada agroforestri sederhana (27,2 $\%)$. Keterjadian penyakit pada buah kopi yang ada di tanah lebih tinggi dibandingkan dengan keterjadian penyakit pada buah yang masih berada di pohon, baik pada sistem agroforestri kompleks (65.3\% vs $45.8 \%)$ maupun pada agroforestri sederhana (61,3 vs $27,2 \%)$.

\section{DAFTAR PUSTAKA}

AEKI. 2011. Realisasi Ekspor Berdasarkan Jenis Kopi Tahun 2010.Tersedia di http://www.aekiaice.org/ $\mathrm{i} \mathrm{mages} / \mathrm{s} \mathrm{t}$ ories/s tat $2011 /$ realisasi_ekspor_berdasarkan_jenis_kopi pdf. Diakses tanggal 15 September 2011.

Afandi. 2004. Benchmark Description : Benchmark and Window Level Information. Progress Report CSM-BGBD Project. Universitas Lampung (Unpublished). pp.1-35.

Aini, F. K., Susilo, F. X., Yanuwiyadi, B. dan Hairiah, K. 2006. Meningkatnya Sebaran Hama Rayap Odontotermes spp. setelah Alih Guna Hutan Menjadi Agroforestri Berbasis Kopi : Efek Perubahan Iklim Mikro dan Ketersediaan Makanan terhadap Kerapatan Populasi. Agrivita $28(3): 221-237$.

Arifin, M., Prayogo, Y. dan Koswanudin, D. 2010. Insektisida Biorasional untuk Mengendalikan Hama Kepik Coklat, Riptortus linearis pada Kedelai. Seminar Nasional Kedelai Balai Penelitian Kacang-Kacangan dan Umbi-Umbian, Malang. Dapat dilihat pada http:// muhammadarifindrprof.blogspot.com/2011/01/ insektisida-biorasional-untuk.html?m=1. Diakses pada tanggal 4 November 2012.

Barnett, H. L. 1960. Ilustrated Genera of Imperfect Fungi. Department of Plant Pathology, Bacteriology and Entomology, West Virginia University. Morgantown, West Virginia. 
Dewi, W. S., Yanuwiyadi, B., Suprayogo, D. dan Hairiah, K. 2006. Alih guna hutan menjadi lahan pertanian : Dapatkah sistem agroforestri berbasis kopi mempertahankan diversitas cacing tanah. Agrivita 28 (3): 198-220.

Fahmi, Z. I. 2003. Studi Karakteristik Iklim Mikro dan Pengaruhnya Terhadap Pertumbuhan, Produksi dan Daya Adaptasi Genotipe-Genotipe Kedelai (Glycine max.(L.) Merr.) pada Empat Tingkat Naungan Buatan. Jurusan Budidaya Pertanian. Fakultas Pertanian. Institut Pertanian Bogor.

Hasyim, A. 2006. Evaluasi Bahan Carrier dalam Pemanfaatan Jamur Entomopatogen, Beauveria bassiana (BALSAMO) Vuillemin untuk Mengendalikan Hama Penggerek Bonggol Pisang, Cosmopolites sordidus Germar. J. Hort. 16 (3):202-210.

Najiyati, S. dan Danarti. 2001. Kopi : Budidaya dan Penanganan Pascapanen. Penebar Swadaya. Jakarta.

Mariani, S. M. dan Junaedi, A. 2009. Pengaruh Intensitas Naungan dan Kombinasi Pemupukan N dan P Terhadap Pertumbuhan, Produksi Simplisia serta Kandungan Andrographolida pada Sambiloto (Andrographis Paniculata). Makalah Seminar Departemen Agronomi Dan Hortikultura, IPB.
Rahayu, S., Setiawan, A., Husaeni, E.A. dan Suyanto, S. 2006. Pengendalian Hama Xylosandrus compactus Pada Agroforestri Kopi Multistrata Secara Hayati: studi kasus dari Kecamatan Sumberjaya, Lampung Barat. Jurnal Agrivita 28 (3).

Soetopo, D. dan Indrayani, I. 2007. Status Teknologi dan Prospek Beauveria bassiana Untuk Pengendalian Serangga Hama Tanaman Perkebunan Yang Ramah Lingkungan. Perspektif 6 (1): 29-46.

Staver, C., Guharay, F., Monterroso, D. dan Munschler, R.G. 2001. Designing pest-suppressive multistrata perennial crop system: Ahade-grown coffea in Central America. Agroforestry Systems 53:151170.

Sudarmo, S. 1989. Tanaman Perkebunan Pengendalian Hama dan Penyakit. Penerbit Kanisius. Yogyakarta. $107 \mathrm{Hlm}$.

Susilo, F. X. dan Karyanto, A. 2005. Methods For Assessment of Below-Ground Biodiversity In Indonesia. Universitas Lampung. Bandar Lampung.

Wulandari, C. 2011. Agroforestri : Kesejahteraan Masyarakat dan Konservasi Sumber Daya Alam. Universitas Lampung. Bandar Lampung. $81 \mathrm{HIm}$.

Yusef, H. M. dan Allan, M.E. 1967. The Effect of Light On Growth and Sporulation of Certain Fungi. Mycopathologia 33 (2) : 81-89. 